DOI: http://dx.doi.org/10.33846/hn40203

http://heanoti.com/index.php/hn

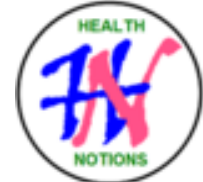

CASE REPORT

URL of this article: http://heanoti.com/index.php/hn/article/view/hn40203

\title{
Management of Hairy Tongue With Oral Candidiasis In Active Smokers
}

\author{
Sri Hernawati ${ }^{1(\mathrm{CA})}$ \\ ${ }^{1(\mathrm{CA})}$ Department of Oral Medicine, Dental Hospital, Faculty of Dentistry, Universitas Jember; \\ srihernawati.drg5@yahoo.com (Corresponding Author)
}

\begin{abstract}
Hairy tongue is an abnormal lengthening of the filiform papillae of the tongue, clinically the dorsum of the tongue looks hair-coated. The etiology of hairy tongue is idiopathic. Predisposing factors for hairy tongue are poor oral hygiene, antibiotics, excessive smoking, oral candidiasis, alcohol consumption, radiation therapy. Candidiasis is an opportunistic infection of the oral cavity caused by Candida albicans (C. albicans). This fungus can cause a pathogenic condition, and is the most common fungal infection found in the human oral cavity. Predisposing factors for oral candidiasis are the use of dentures, xerostomia, stress, and smoking habits. Objective: To demonstrate the management of a case of hairy tongue with oral candidiasis on the dorsum of the tongue. Case: A 54-year-old male patient came to the Dental Hospital of Jember University for treatment with a complaint of feeling thick and yellowish-brown color on the back of the tongue with clinical features of an extension of the papillae filiformis in the posterior third of the dorsum of the tongue, and a white-yellowish white plaque, could be scraped, but not sick. The patient had complained it since \pm 3 years ago. The patient claimed to have never had his tongue scraped off and never treated it. In addition, he smoked a pack of cigarette a day and consumed coffee every morning and evening. Conclusion: The final diagnosis in the patient was hairy tongue with oral candidiasis on the dorsum of the tongue. Therapy provided to the patient i.e. Nystatin oral suspension functions as a topical antifungal medication, Becomzet multivitamin (Vitamin B complex, A, C, E, and Zinc) as a multivitamin and Tongue cleaner as a tongue cleaner. Dental and oral health education was conducted for preventing hairy tongue.
\end{abstract}

Keywords: hairy tongue; oral candidiasis; active smokers

\section{INTRODUCTION}

\section{Background}

Hairy tongue is an abnormal lengthening of the filiform papillae of the tongue, clinically the dorsum of the tongue looks hair-coated. This condition is a hypertrophic response associated with increased keratin deposition or delayed flaking of the horn. The patient who does not clean his tongue is the person most often affected by this condition. ${ }^{(1)}$ The etiology of hairy tongue is idiopathic. Predisposing factors for hairy tongue are poor oral hygiene, antibiotics, excessive smoking, oral candidiasis, alcohol consumption, radiation therapy. ${ }^{(2)}$ Epidemiologically from the United States and Scandinavia, the prevalence of hairy to.gue is reported to be below $1 \%{ }^{(3)}$ While in Turkey, the prevalence is reported to be $11.3 \%$ which is more prevalent in males $(18 \%)$ than females $(6 \%)$. Its frequency increases with age and consumption of a soft diet. ${ }^{(4)}$

Hypertrophy and lengthening of the filiform papillae look like feathers/ hair. Usually less than $1 \mathrm{~mm}$, the length can reach 12-18 $\mathrm{mm}$ and the width of $2 \mathrm{~mm}$. Then collecting fungi, bacteria, and debris, may include residues from tobacco, coffee, tea, and other foods, as well as porphyrin-producing chromogenic organisms in oral flora, which provide colorful lesions. ${ }^{(4)}$

Hairy tongue management can be done by brushing the tongue every day with a tongue cleaner or abrasive paste coupled with eliminating predisposing factors can eliminate this condition. The use of topical triamcinolone acetoneide, acid trichloroacet has been reported in the literature, although potential side effects from local irritation and possible systemic absorption are important factors to consider. ${ }^{(4)}$ 
Oral candidiasis is an opportunistic infection in the oral cavity caused by the fungus Candida albicans i.e. flora of the oral cavity which can turn into pathogens in certain circumstances, especially when the body has decreased endurance. Candida albicans is an agent that mainly cause of infection, especially in the dorsum of the posterior tongue. Oral candidiasis can result from taking broad-spectrum antimicrobial drugs (for example: Tetracycline), users of dental prostheses, smokers, immunocompromised conditions (HIV disease, Down's syndrome, malnutrition, or Diabetes Mellitus), and hospitalized patients. ${ }^{(5,6)}$ Oral candidiasis infection has several clinical features, acute pseudomembrane candidiasis (thrush), acute athropic candidiasis, chronic athropic candidiasis, and chronic hyperplastic candidiasis. Epidemiologically, the World Health Organization (WHO) reported that in 2001 oral candidiasis frequency was $5.8 \%$ to $98.3 \%$. $^{(7)}$

The pathogenesis of oral candidiasis starts from the attachment of yeast to the epithelium (host cell). This attachment can occur due to specific combination mechanisms (interactions between ligands and receptors) and non-specific (electrostatic poles and van der walls bonds). The next process is the activation of mitogen activated protein kinase (Map-kinase) by stress conditions at the place where the yeast and host cells make contact. The map-kinase is necessary for the growth of yeast to hyphae. After 48 hours, yeast has been seen to penetrate and develop hyphae in the host cell because the $\mathrm{pH}$ around $(\mathrm{pH} \mathrm{5)}$ is the same as the optimal $\mathrm{pH}$ of C. albicans. The body's defenses will be difficult to deal with the spread of the infection because $\mathrm{C}$. albicans can induce suppressive T cell and B cell activity. ${ }^{(8)}$ Predisposing factors for oral candidiasis include endocrine disorders, nutritional disorders, malignancies, hematological disorders, immune disorders, serostomia, drugs (corticosteroids, or broad-spectrum antibiotics in the long term), dentures and smoking. The patient's age and smoking habits lead to disturbanceof salivary secretion. Saliva plays an important role in maintaining homeostasis and microflora of the oral cavity, including in preventing fungal infections.

Saliva has a self-cleansing effect that dissolves pathogenic antigens and clears the oral mucosa. Salivary antibody (sIgA) and anti-microbial factors in saliva (lysozyme, lactoperoxidase, histatin, kalprotectin, and lactoferin) play an important role in preventing attachment, colonization, and Candida albicans infection.

Thus, a decrease in the rate of saliva may cause a decrease in the efficiency of the immune system as a control for Candida albicans infection so as to facilitate the occurrence of Candida albicans infection. In oldaged patients with cell proliferation or regeneration of epithelial cells are also disturbed thus it is susceptible to disease. $^{(5)}$

\section{METHODS}

Thus, a decrease in the rate of saliva may cause a decrease in the efficiency of the immune system as a control for Candida albicans infection so as to facilitate the occurrence of Candida albicans infection. In oldaged patients with cell proliferation or regeneration of epithelial cells are also disturbed thus it is susceptible to disease. $^{(5)}$

\section{RESULTS}

\section{Visit I (September 12, 2019)}

Male patient aged 54 years, Madurese with $63.5 \mathrm{~kg}$ body weight and $155 \mathrm{~cm}$ height. The patient came to the Oral Medicine Department of Jember University Dental Hospital on September 12, 2019 with a complaint of feeling thick and yellow-brown on the back of the tongue with clinical features there was an extension of the filiform papillae in the posterior third of the dorsum of the tongue, and there were white-yellowish-white plaques, which could be scraped off, but not sick. The patient complained that his tongue had been felt thick for \pm 3 years. The patient said that never had his tongue scraped off and never treated it. In addition, he smoked a pack of cigarette containing 20 cigarettes a day and consumed coffee every morning and evening, and at that time the the tongue now did not hurt.

Extra oral clinical examination found no abnormalities. On intraoral examination, there were remaining root teeth on teeth $11,14,16,17,22,23,24,26$, and 42 . There was an extension of the papillary filiform in one third of the dorsum of the tongue, yellow-brown, in addition there was a yellowish-white plaque, could be scraped off, and not hurt.

The condition of the tongue of the patient when he first visited the Dental Hospital on 13 September 2019 can be seen in Figure 2.

Case diagnosis was hairy tongue. In addition, it was also carried out a supporting examination of oral swabs at the Microbiology Laboratory of Dental Hospital, Jember University to establish the diagnosis. The result of oral swab showed spores +3 (positive 3 ) and hypha +2 (positive 2), thus the diagnosis could be made in the form of oral candidiasis on the dorsum of the tongue. 


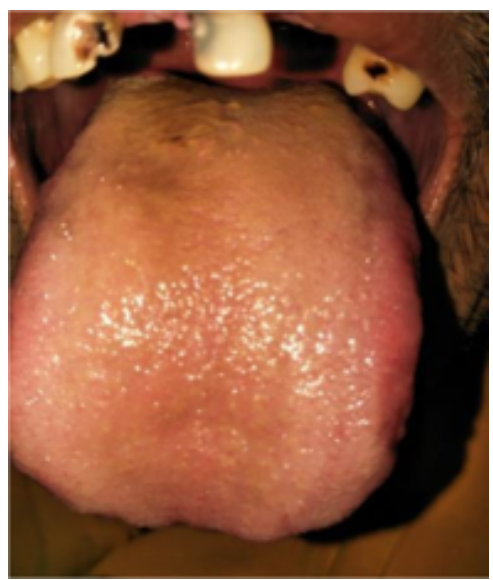

Figure 2. The condition of the patient's tongue when he first visited the dental hospital on September 13, 2019

\section{Treatment}

Therapy managed to patient was in the form of causative therapy using antifungal topical oral nystatin suspension, tongue cleaner and supportive therapy by administering multivitamin becomzet containing B complex, vitamins A, C, E, and Zinc, and instructions to be applied at home. The therapies carried out at the Dental Hospital during the first visit were oral candidiasis therapy in the following ways:

1. The patient is instructed to rinse his mouth water

2. Dry the patient's tongue using a tampon

3. Oral swab was carried out on the patient's tongue.

- Fixation of glass objects above the Bunsen flame

- Swab using a spatula disposable, clean the debris with a disposable spatula, the disposable spatula is fixed over fire Bunsen. Wait until the spatula cools again.

- Samples are placed on glass objects

- The preparation is closed with a glass cover

- Immediately sent to the Microbiology Laboratory.

4. Topical treatment was conducted using antifungal (nystatin oral suspension), dripped on the tongue with 0.5 $\mathrm{ml}$ cotton palate and flattened, and subsequently allowed for 2-3 minutes, after that it may be swallowed, and might not be thrown away.

5. The patient was instructed not to eat, to drink, or to gargle for 20-30 minutes after the application of the medicine.

After the therapy, the patient was instructed to use the antifungal medicine i.e. nystatin and the multivitamin becomzet as recommended, maintain oral hygiene especially the tongue using a tongue cleaner, not smoking, eating nutritious food, having adequate rest, and going for check up 1 week later.

\section{Visit II (19 September 2019)}

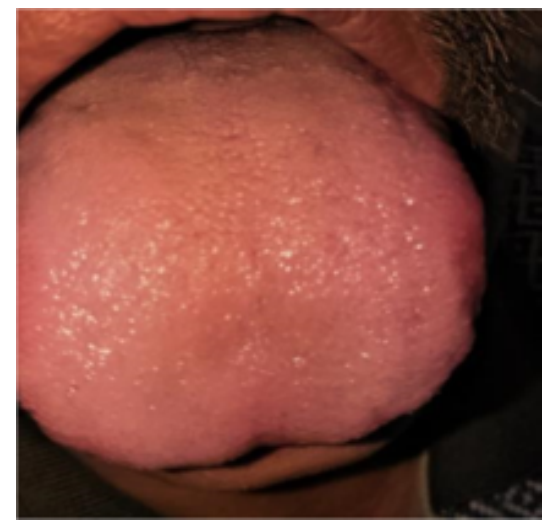

Figure 2. On September 19, 2019, the patient came back to the dental hospital for checkup 
On September 19, 2019, the patient returned to the Dental Hospital for checkup (Figure 2). The patient told that his tongue was not thick anymore, and felt more comfortable. On extra oral examination no abnormalities were found and intraoral examination was not found any lengthening of the filiform papillae on the tongue, the tongue was red and did not feel painful. The patient said that he had used the medicine according to the rules, Nystatin remained a little, and Becomzet multivitamin was used up, and the use of tongue cleaner was routine.

\section{DISCUSSION}

The final diagnosis is established based on subjective examination results in the form of anamnesa, extra oral and intra oral clinical examination, and supporting examination in the form of a swab test at the Microbiology Laboratory of Jember University. Based on the results of these examinations, a final diagnosis is obtained in the form of hairy tongue accompanied by oral candidiasis. In this case, the suspected cause of hairy tongue accompanied by oral candidiasis in this patient was due to lack of maintaining oral hygiene. In addition, patient has a habit of smoking for less than 20 years which is a factor that can initiate the occurrence of hairy tongue. In previous studies, hairy tongue was experienced with age, and in patients over 60 years. ${ }^{4}$ Changes to the tongue in smokers come from irritation, toxins and carcinogenic substances produced by burning tobacco, high temperatures, changes in $\mathrm{pH}$ of the oral cavity, decreased immune system and fungal and bacterial infections in the oral cavity. Hot smoke that blows continuously into the oral cavity is a heat stimulus that causes changes in blood flow and reduces salivation. As a result the oral cavity becomes drier and more anaerobic to provide an appropriate environment for the growth of bacteria. In smokers a decrease in immune substances ( $\operatorname{IgA}$ antibodies) found in saliva thus the balance of the oral cavity is disrupted. As a result, the balance of keratin growth on the surface of the tongue becomes disrupted and papillary filiform hyperkeratosis occurs. 4

The treatment administered to the patient is oral suspension nystatin as a causative therapy. Nystatin at a dose of $100000 \mathrm{IU} / \mathrm{ml}$ has been used for many years because it absorbs very little by the intestinal tract, consequently it has very low hepatotoxicity. Nevertheless, taste and long-term use are common complaints from many patients. ${ }^{9}$ Nystatin is a polyene macrolide whose toxicity is low if used as a topical medication, effective against most Candida species, and most often used to suppress local Candida infections. Antifungal polyene binds to elgosterol in the fungi cell membrane, so that there is a disruption in the structure of the cell membrane that causes intracellular leakage which ends in cell death. In addition to nystatin, a tongue cleaner is also used as a mechanical causative therapy for cleaning the fungus Candida albicans on the tongue. ${ }^{10}$

Besides, patients are also administered a multivitamin as supportive therapy hence the process of repairing cells damaged by Candida albicans infection can take place more quickly and to restore the immune system in order to prevent recurrent infections. The patient was also instructed to maintain oral hygiene especially the tongue by diligently using a tongue cleaner, not smoking, eating nutritious food, having adequate rest, and consuming lots of water.

\section{REFERENCES}

1. Langlais RP, Miller CS, Nield- Gehrig JS. Colored atlas of oral lesions that are often found (Atlas berwarna lesi mulut yang sering ditemukan). $4^{\text {th }}$ Edition. Jakarta: EGC; 2013.

2. $\quad$ Laskaris G. Pocket Atlas of Oral Disease. $2^{\text {nd }}$ Edition. New York: Thieme; 2006.

3. Greenberg MS, Glick M, Ship J. Burket's Oral Medicine. 1 ${ }^{\text {th }}$ Edition. Hamilton: BC Decker Inc.; 2008.

4. Gurvits GE, Tan A. Black Hairy Tongue Syndrome. World JGastroenterol. 2014;20(31):10845-10850.

5. Hidayat W, Nanan N, Tenny S, Erna H, Indah S. Oral Candidiasis Profile in the Oral Medicine Division, Dr. Hasan Sadikin Hospital (RSHS) Bandung, Period 2010-2014 (Profil Kandidiasis Oral di Bagian Ilmu Penyakit Mulut Rumah Sakit Dr. Hasan Sadikin (RSHS) Bandung Periode 2010-2014). Maj Ked Gi. 2016;2(2).

6. Nur'aeny NW, Hidayat TS, Dewi E, Herawati IS Yuni. Oral profile of candidiasis in the oral disease department, RSHS Bandung, 2010-2014 period (Profil oralcandidiasis di bagian ilmu penyakit mulut RSHS Bandung periode 2010-2014). Majalah Kedokteran Gigi Indonesia. 2017;3(1).

7. Walangare T, Taufiq H, Santosa B. Candida Species Profile in Oral Candidiasis Patients with HIV AIDS Infection (Profil Spesies Candida pada Pasien Kandidiasis Oral dengan Infeksi HIV\&AIDS). Periodical of Dermatology and Venereology. 2014;26(1).

8. Kusumaningtyas E. Mechanisms of Candida albicans Infection on Cell Surface (Mekanisme Infeksi Candida albicans pada Permukaan Sel). Bogor: Lokakarya Nasional Penyakit Zoonosis. 
9. Nunez MJ, Balboa, Riveiro, Linares, Mana P, Rey-Mendez A, Rodriguez-Cobos JA, Suarez-Quintanilla LA, García-Vallejo M, Freire-Garabal. Effects of Psychological Stress and Alprazolam on Development of OralCandidiasis in Rats. JournalsASM. Org. 2002;9(4).

10. FK UI. Pharmacology and Therapy (Farmakologi dan Terapi). Edisi 5. Jakarta: FK UI; 2007. 